\title{
Sustained Remission of a Primary Nodal Merkel Cell Carcinoma in an HIV-Positive Patient
}

\author{
Pierluigi Brugnaro $^{\mathrm{a}} \quad$ Erika Morelli $^{\mathrm{a}}$ Marta Fiscon $^{\mathrm{a}}$ Francesca Ebo $^{\mathrm{a}}$ Giorgio Rosini $^{\mathrm{a}}$ \\ Fabio Belussi $^{\mathrm{a}}$ Franklyn Eseme $^{\mathrm{a}} \quad$ Carlo A. Mione $^{\mathrm{b}} \quad$ Pietro M. Donisi $^{\mathrm{c}} \quad$ Enzo Raise $^{\mathrm{a}}$ \\ anfectious Diseases Division, \\ ${ }^{\mathrm{b}}$ Oncology and Radiotherapy Service, \\ 'Pathology Department, 'SS.Giovanni e Paolo' Hospital, Venice, Italy
}

\section{Keywords}

Chemotherapy · HIV infection - Merkel cell carcinoma . Radiotherapy

\section{Introduction}

Merkel cell carcinoma (MCC) is an uncommon, highly malignant skin cancer of neuroendocrine origin that occurs more often in sun-exposed areas of the body, such as the head and neck, and generally affects elderly patients. The tumor is clinically aggressive, showing a high propensity for local, regional, and distant spread. An increased incidence of MCC has been reported in association with other malignancies, immunosuppressive treatments following organ transplantation, and human immunodeficiency virus (HIV) infection.

\section{Case Report}

The patient, now aged 66 years, was found to be HIV positive in 1984 after an occupational accident in a hospital where he was working as a nurse. 2 years after the initial diagnosis he developed pleural tuberculosis, but he had no further hospital admissions related to acquired immunodeficiency syndrome (AIDS)-defining diseases. He was treated with sequential and dual nucleoside therapy until 1996, when he started highly active antiretroviral therapy (HAART), and his current medications were unboosted saquinavir, lamivudine and stavudine. He also had hypertension, hyperlipidemia, and lipoatrophy. The patient was also treated from 2004 to 2007 with recombinant interleukin-2 (IL-2) as he had been enrolled in an international multicenter study [1]. In April 2008, the patient was admitted to our department because of a painful left inguinal mass that had grown slowly during the previous 3 months. His CD4 T lymphocytes were $479 / \mu \mathrm{l}$ and plasma HIV-RNA was consistently below 40 copies $/ \mathrm{ml}$. 2 years before this evaluation, a squamous cell carcinoma had been removed from the skin of the penis. A biopsy of the inguinal nodule revealed a dense growth of malignant cells infiltrating the lymph nodes and subcutaneous tissues, with areas of necrosis and fluid collections. A positron emission tomography (PET) scan displayed a markedly increased activity at this nodal location, and a computed tomography (CT)

\section{KARGER}

Fax +497614520714

Information@Karger.de

www.karger.com

\section{(c) 2011 S. Karger GmbH, Freiburg}

0378-584X/11/0344-0190\$38.00/0

Accessible online at:

www.karger.com/onk scan of the chest and abdomen did not show any pathological lesions at other sites. Wide surgical resection of the tumor with inguinal lymph node excision was performed, and the pathological examination with immunohistochemical studies (positive cytokeratin 20, neuron-specific enolase and synaptophysin staining; negative cytokeratin 7 and thyroidtranscription factor-1 staining) led to a confirmed diagnosis of MCC stage III, according to the system proposed by Allen et al. [2] (figs. 1-4). The patient underwent postoperative radiotherapy of the inguinal nodal disease for a total of $45 \mathrm{~Gy}$ administered over 25 treatment sessions. It was also decided to start adjuvant combination chemotherapy with carboplatin and etoposide, which the patient received for 6 rounds over a 3 -month period. The treatment was well tolerated by the patient and HAART was not discontinued. At the end of the radiation and chemotherapy cycles, the absolute count of the patient's CD4 T cells fell to $170 / \mu l$ but the viral load still remained undetectable, and neither opportunistic diseases nor severe drug-related side effects were experienced. The patient is now 24 months since the initial diagnosis of MCC and 18 months since completion of oncological treatment, with no clinical evidence of disease relapse, and a total body PET-CT scan did not demonstrate any pathological findings.

\section{Discussion}

MCC is an unusual cutaneous malignancy that is seen primarily in the older white population. Based on data from the U.S. Surveillance, Epidemiology and End Results (SEER) program, the incidence rate of MCC has tripled from 0.15 per 100,000 in 1986 to 0.44 per 100,000 in 2001 [3]. Many patients with MCC have had a history of other synchronous or metachronous sun-associated skin cancers, implying that excessive sun exposure is a pathogenetic factor for developing MCC [4]. This malignancy has also been observed as a second primary cancer among patients with multiple myeloma, chronic lymphocytic leukemia, and non-Hodgkin's lymphoma [5]. Even though MCC is not considered an AIDS-defining disease like Kaposi's sarcoma, non-Hodgkin's lymphoma, and cervical carcinoma, the relative risk of MCC has been shown to be 13.4 in HIV-positive patients compared with the general population [6]. Recently, a small novel polyomavirus, 


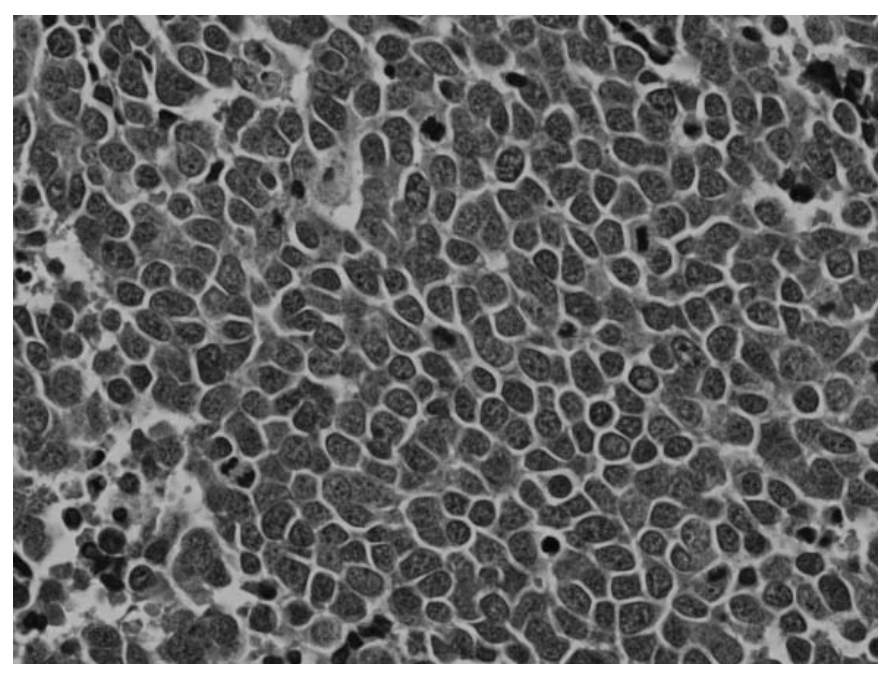

Fig. 1. Biopsy specimen of the inguinal lymph node: hematoxylin/eosin staining (magnification $40 \times$ ). The cells appear with a scanty cytoplasm and vesicular nuclei with a salt-and-pepper-like chromatin. Mitotic figures are also present.

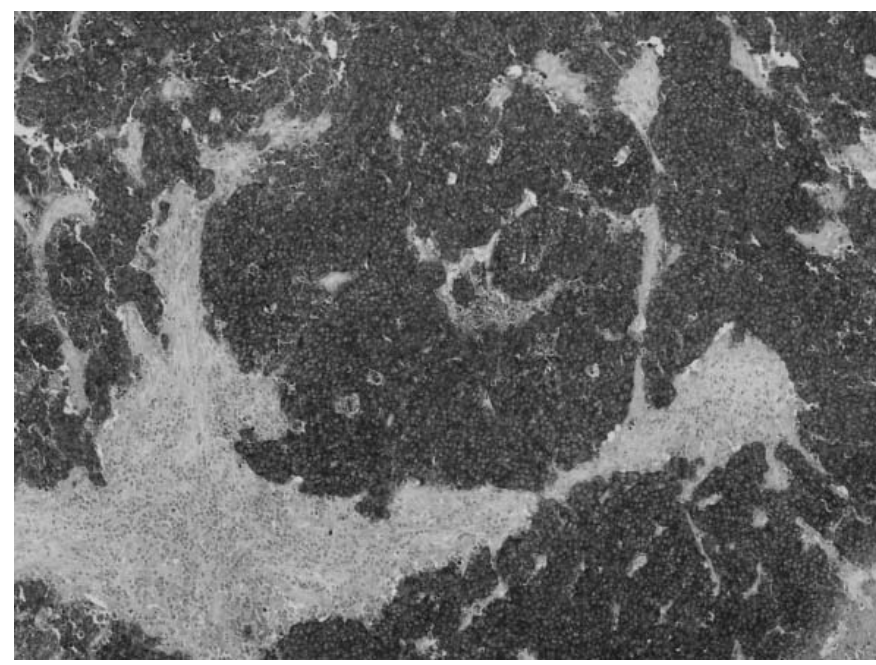

Fig. 3. Biopsy specimen of the inguinal lymph node: Immunohistochemical staining for neuron-specific enolase was positive on tumoral cells (magnification $20 \times$ ).

provisionally named Merkel cell polyomavirus (MCPyV), was found in MCC tissue, suggesting a role of this virus in the pathogenesis of the carcinoma [7]. The prevalence of MCPyV DNA in MCCs may vary in different populations [8]. We did not perform the MCPyV DNA analysis in the tissue sample: This is a limitation of our work. Reviewing our case and the 11 patients with MCC and HIV infection reported in the literature (table 1) [9-19], the mean age was 50 years (range, 25-66) whereas the mean age among non-HIV-infected patients with MCC is 69 years. The mean time from HIV diagnosis to the onset of MCC was 12 years (range, 3-25 years). In 4 out of 9 patients, the CD4 T lymphocyte count was below 200 cells $/ \mu$ l (36\%), and only 1 patient was reported to have had an opportunistic disease before MCC diagnosis. Involvement of regional lymph nodes (stage III) was present in 6 out of 12 patients $(50 \%)$. Our case is remarkable since no primary lesion was found. A similar presentation was previously

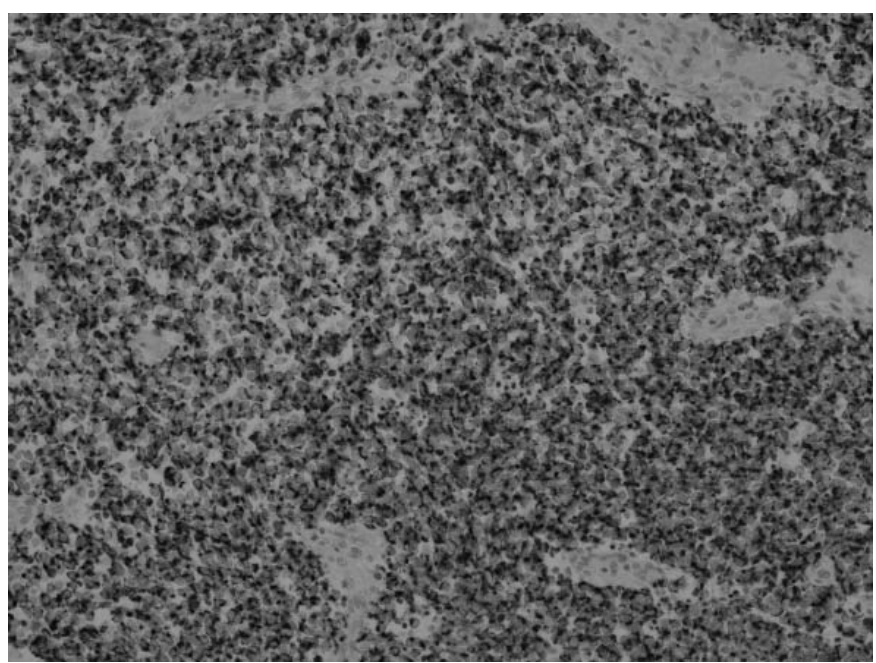

Fig. 2. Biopsy specimen of the inguinal lymph node: Immunohistochemical staining for cytokeratin 20 on the tumoral cells shows a dotlike pattern (magnification $20 \times$ ).

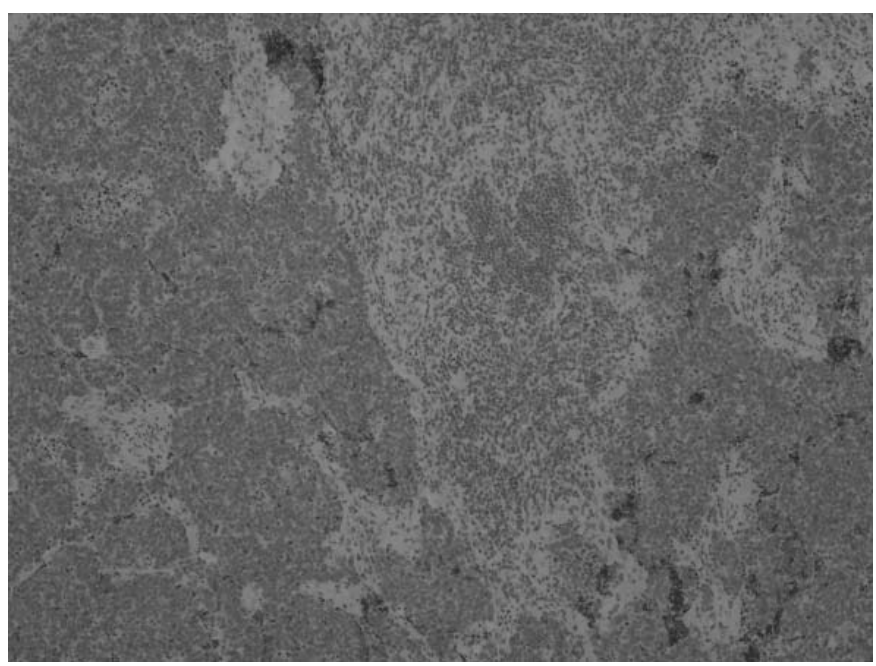

Fig. 4. Biopsy specimen of the inguinal lymph node: Immunohistochemical staining for thyroid-transcription factor-1 was negative on tumoral cells (magnification $20 \times$ ).

described by Samarendra et al. [12]. All patients reported in the literature underwent surgery; 9 out of 12 patients $(75 \%)$ received radiation therapy. Although recent studies have not demonstrated a significant survival benefit with the addition of chemotherapy [20], and despite the risk of administering systemic chemotherapy to immunosuppressed patients such as HIV-positive individuals, the majority of patients also received adjuvant chemotherapy (8 out of 12 patients, $67 \%$ ). The association of etoposide and cisplatin (or carboplatin) was the most commonly used chemotherapy regimen. The good Karnofsky performance status of our patient and the stable control of HIV infection obtained with HAART encouraged us to administer adjuvant chemotherapy, which was well tolerated. It is noteworthy that another HIV-positive patient who developed MCC was subsequently treated with IL-2 combined with HAART and the cancer regressed [13]. In our case, administration of IL-2 preceded the MCC onset. At 
Table 1. Clinical findings, treatment and outcome of 12 cases of HIV-associated MCC

\begin{tabular}{|c|c|c|c|c|c|c|c|c|c|}
\hline $\begin{array}{l}\text { Reference } \\
\text { number }\end{array}$ & Sex & $\begin{array}{l}\text { Age at MCC } \\
\text { diagnosis, } \\
\text { years }\end{array}$ & MCC location & $\begin{array}{l}\text { Time from } \\
\text { HIV infection } \\
\text { to MCC, years }\end{array}$ & $\begin{array}{l}\text { CD4+ count, } \\
\text { cells/ul }\end{array}$ & $\begin{array}{l}\text { Previous } \\
\text { opportunistic } \\
\text { diseases }\end{array}$ & $\begin{array}{l}\text { MCC } \\
\text { stage }\end{array}$ & Treatment & $\begin{array}{l}\text { Survival, } \\
\text { months }\end{array}$ \\
\hline 9 & $\mathrm{f}$ & 36 & ear lobe & 14 & 63 & none & II & surgery & $>9$ \\
\hline 10 & $\mathrm{f}$ & 25 & face & unknown & 332 & unknown & III & surgery, RT, CT & 11 \\
\hline 11 & $\mathrm{~m}$ & 57 & finger & 14 & $357-573$ & none & I & surgery, RT, CT & $>40$ \\
\hline 12 & $\mathrm{~m}$ & 40 & inguinal node & 3 & 160 & none & II & surgery & $>42$ \\
\hline 13 & $\mathrm{~m}$ & 52 & buttock & 10 & 267 & unknown & III & surgery, RT & $>11$ \\
\hline 14 & $\mathrm{~m}$ & 47 & buttock & unknown & 625 & unknown & III & surgery, RT, CT & $>23$ \\
\hline 15 & $\mathrm{~m}$ & 48 & scalp & 12 & $\begin{array}{l}\text { within normal } \\
\text { range }\end{array}$ & none & III & surgery, RT, CT & 12 \\
\hline 16 & $\mathrm{~m}$ & 60 & nasal bridge & unknown & unknown & unknown & I & surgery, RT & 21 \\
\hline 17 & $\mathrm{~m}$ & 51 & gluteus & 6 & 122 & unknown & II & surgery, RT, CT & 9 \\
\hline 18 & $\mathrm{~m}$ & 54 & arm & unknown & 82 & unknown & II & surgery, CT & 25 \\
\hline 19 & $\mathrm{~m}$ & 63 & head & 12 & 232 & $\begin{array}{l}\text { Pneumocystis } \\
\text { pneumonia }\end{array}$ & III & surgery, RT, CT & 15 \\
\hline Present case & $\mathrm{m}$ & 66 & inguinal node & 25 & 479 & none & III & surgery, RT, CT & $>24$ \\
\hline
\end{tabular}

$\mathrm{CT}=$ Chemotherapy; $\mathrm{RT}$ = radiotherapy .

present, the role of recombinant IL-2 in combination with HAART for the treatment of HIV infection is still questionable since a randomized multicenter study recently failed to demonstrate that IL-2 in combination with antiretroviral therapy reduces the rate of opportunistic diseases or death [1]. At the time of last follow-up, 6 patients with MCC (50\%) were alive and the mean time of follow-up for these patients was 25 months (range, 9-42 months). MCC is a rare but very aggressive tumor that has been reported with a higher incidence in HIV-positive individuals than in the general population. Reviewing the management of the HIV-positive patients with MCC, only 2 patients with local disease underwent surgical intervention alone. Immunosuppression or the risk of toxicity and HAART discontinuation did not discourage the majority of authors from administering adjuvant radiation and chemotherapy. Such interventions should be considered because of the high risk of locoregional and distant relapse of this cancer. Until data from multi-institutional trials are collected, the role of adjuvant radiation therapy and chemotherapy for MCC will continue to be debated.

\section{Disclosure Statement}

The authors state no financial or personal relationships with other persons or organizations that inappropriately influenced this work.

\section{References}

1 INSIGHT - ESPRIT Study Group; SILCAAT Scientific Committee, Abrams D, Lévy Y, Losso MH, Babiker A, Collins G, Cooper DA, Darbyshire J, Emery S, Fox L, Gordin F, Lane HC, Lundgren JD, Mitsuyasu R, Neaton JD, Phillips A, Routy JP, Tambussi G, Wentworth D: Interleukin-2 therapy in patients with HIV infection. N Engl J Med 2009;361:1548-1559.

$\checkmark 2$ Allen PJ, Bowne BW, Jaques DP, Brennan MF, Busam K, Coit DG: Merkel cell carcinoma: prognosis and treatment of patients from a single institution. J Clin Oncol 2005;23:2300-2309.

$\checkmark 3$ Hodgson NC: Merkel cell carcinoma: changing incidence trends. J Surg Oncol 2005;89:1-4.

$\checkmark 4$ Brenner B, Sulkes A, Rakowsky E, Feinmesser M, Yukelson A, Bar-Haim E, Katz A, Idelevich E, Neuman A, Barhana M, Fenig E: Second neoplasms in patients with Merkel cell carcinoma. Cancer 2001;91:1358-1362.

5 Vlad R, Woodlock TJ: Merkel cell carcinoma after chronic lymphocytic leukemia: case report and literature review. Am J Clin Oncol 2003;26:531-534.

6 Engels EA, Frisch M, Goedert JJ, Biggar RJ, Miller RW: Merkel cell carcinoma and HIV infection. Lancet 2002;359:497-498.

7 Feng H, Shuda M, Chang Y, Moore PS: Clonal integration of a polyomavirus in human Merkel cell carcinoma. Science 2008;319:1096-1100.
8 Garnesky KM, Warcola AH, Feng Q, Kiviat NB, Leonard JH, Nghiem P: Merkel cell polyomavirus is more frequently present in North American than Australian Merkel cell carcinoma tumors. J Invest Dermatol 2009;129:246-248.

9 Matichard E, Descamps V, Grossin M, Genin R, Bouvet E, Crickx B: Merkel cell carcinoma in a black human immunodeficiency virus-infected patient. Br J Dermatol 2002;146:671-673.

10 Colebunders R, Bottieau E, Van den Brande J, Colpaert C, Van Marck E: Merkel cell carcinoma and multiple basal cell carcinoma in an African albino woman with HIV infection. HIV Med 2004;5:452-454.

11 Cone LA, Gade-Andavolu R, Lesnick RH, Aitken D, Bush WS, Potts BE: Merkel cell carcinoma in an HIV-1-infected man. AIDS 2006;20:474-475.

12 Samarendra P, Berkowitz L, Kumari S, Alexis R: Primary nodal neuroendocrine (Merkel cell) tumor in a patient with HIV infection. South Med J 2000;93:920-922.

13 Burack J, Altschuler EL: Sustained remission of metastatic Merkel cell carcinoma with treatment of HIV infection. J R Soc Med 2003;96:238-239.

14 Cattel JP, Todd WM, Carr ME Jr: Merkel cell carcinoma in an HIV-positive patient. Va Med Q 1992;119:256-258.
5 Solomon RK, Lundeen SJ, Hamlar DD, Pambuccian SE: Fine-needle aspiration diagnosis of unusual cutaneous neoplasms of the scalp in HIV-infected patients: a report of two cases and review of the literature. Diagn Cytopatho 2001;24:186-192.

16 An KP, Ratner D: Merkel cell carcinoma in the setting of HIV infection. J Am Acad Dermatol 2001;45:309-312.

17 Calza L, Beltrami C, Manfredi R, Colangeli V, Freo E, Chiodo F: Merkel cell carcinoma in a human immunodeficiency virus-infected patient. Br J Dermatol 2002;146:895-898.

18 Manganoni MA, Farisoglio C, Tucci G, Venturini M, Marocolo D, Aquilano MC El-Hamad I, Ferrari VD, Calzavara Pinton PG: Merkel cell carcinoma and HIV infection: a case report and review of the literature. AIDS Patient Care STDS 2007;21:447-451.

19 Busse PM, Clark JR, Muse VV, Liu V: Case 19 2008: a 63-year-old HIV-positive man with cutaneous Merkel cell carcinoma. N Engl J Med 2008;358:2717-2723.

20 Eng TY, Boersma MG, Fuller CD, Goytia V, Jones WE, Joyner M, Nguyen DD: A comprehensive review of the treatment of Merkel cell carcinoma. Am J Clin Oncol 2007;30:624-636. 